\title{
Polysèmes
}

Revue d'études intertextuelles et intermédiales

\section{Enfermement et correspondances chez Patrick White}

\author{
Anne Le Guellec
}

\section{(2) OpenEdition}

Journals

Édition électronique

URL : http://journals.openedition.org/polysemes/1607

DOI : 10.4000/polysemes. 1607

ISSN : 2496-4212

Éditeur

SAIT

Édition imprimée

Date de publication : 1 janvier 2003

Pagination : 81-93

ISSN : 0999-4203

\section{Référence électronique}

Anne Le Guellec, «Enfermement et correspondances chez Patrick White », Polysèmes [En ligne],

6 | 2003, mis en ligne le 10 janvier 2017, consulté le 01 mai 2019. URL : http://

journals.openedition.org/polysemes/1607 ; DOI : 10.4000/polysemes.1607

Ce document a été généré automatiquement le 1 mai 2019.

Polysèmes 


\title{
Enfermement et correspondances chez Patrick White
}

\author{
Anne Le Guellec
}

1 La critique dite post-coloniale a montré que contre le modèle impérial fondé sur les notions de centre et de périphérie se sont élaborées dans les « nouvelles littératures » des tentatives pour conjurer la "dislocation » liée à l'expérience de la migration forcée ou volontaire, combinée à une dénigration culturelle. Dans l'univers excentrique de l'Australie, le problème du rapport identitaire au lieu se pose à la conscience "blanche " de manière particulièrement complexe du fait des origines pénitentiaires de la colonie d'une part, et d'autre part du fait de la culpabilité liée à la participation à l'oppression de la population autochtone. Doublement coupée de l'univers dans lequel pourtant il lui faut s'enraciner, la société australienne coloniale que présente l'œuvre de Patrick White reste recroquevillée sur les marges du continent, se sclérosant peu à peu dans la bulle protectrice des grandes maisons à l'anglaise, et derrière l'écran d'un imaginaire importé. La matérialité même de l'espace australien semble défier l'immigrant de jamais parvenir à construire un espace de sens ${ }^{1}$, jusqu'à ce que des personnages exceptionnels, comme Voss, parviennent à trouver des passages vers l'intérieur du continent et de la conscience australienne, inscrivant de leur sang une nouvelle légende sur la terre aborigène. C'est à ce prix qu'il est possible aux personnages de White de se libérer d'un système sclérosé dont la structure labyrinthique des passages montre assez que le sens n'y circule plus.

Dans l'univers clos des grandes maisons bourgeoises, la description ne s'arrête sur les "passages» que lorsque, paradoxalement, ils cessent d'être transitoires. Les passages conçus comme espaces de transit sont réduits, par la visée tendue vers un au-delà, à n'être qu'une parenthèse sans épaisseur spatiale ni temporelle. Mais lorsqu'ils cessent d'être une simple fonction, et qu'ils accèdent au statut de construction concrète, les passages whitiens sont effectivement « dérobés aux jours ». L'obscurité qui règne dans cet espace dépourvu de repères, désoriente la visée transitive et l'emprisonne dans une durée qui empiète sur la temporalité évolutive des espaces extérieurs. Alors que la parenthèse du passage purement transitoire a vocation à s'effacer derrière sa fonction, le passage whitien, en pervertissant les dimensions spatio-temporelles, s'affirme comme monde à 
part entière, et l'expérience que les personnages en font apparaît comme un enfermement dans le non-sens.

3 Certes, associer la notion d'enfermement aux passages semble moins surprenant en anglais qu'en français, du fait que le terme désigne davantage l'espace confiné des couloirs d'une maison que les «traboules » citadines permettant la communication entre des espaces plus ou moins contrastés. Le « passage » anglais y perd donc en dynamisme de transition puisqu'il ne permet la circulation que d'une pièce à l'autre à l'intérieur du système fermé qu'est la maison (c'est le « hall » et non le passage qui permet l'accès à la porte d'entrée - ou de sortie).

Mais les passages chez White ne donnent même plus accès à des pièces familières. Ils prennent au contraire l'aspect oppressant d'un labyrinthe :

Rounding a corner, Mrs Jolley realized she had overshot the flight of stairs which

led higher to her room. And here were the passages of Xanadu, endless before her. ${ }^{2}$

Dans ces interminables passages, les portes sont closes ou effacées, ou même remplacées par des miroirs qui n'ouvrent que de fausses perspectives et accentuent encore l'enfermement. Pourtant, les personnages prisonniers de ces passages doivent faire un effort sur eux-mêmes pour s'en arracher, la suspension du temps et la relativisation de l'espace constituant une sorte de limbes, où l'individu est déresponsabilisé. Ainsi, malgré l'incendie qui fait rage dans la maison où il se trouve, Stan Parker dans The Tree of Man oublie le danger et perd tout sentiment d'urgence :

Time was becalmed in the passages. [...] So close was the protective darkness, which the smoke had not entered, it was not possible to be afraid. You listened for voices the other side of the wall, of people who had not died.

So that he had to tear himself from the passages and return to a desperate situation .

6 Ces limbes possessives mais rassurantes représentent aussi un abri contre les agressions de l'existence pour Mary Hare, dans Riders in the Chariot. Comme le lui faisait cruellement remarquer son père, elle est " one of the unborn $»^{4}$. Sa difformité physique mais surtout son retard mental l'empêchent en effet d'entrer dans le processus évolutif de la vie, de faire l'expérience de l'altérité, de s'arracher comme Stan Parker au cercle fermé des passages dans lequel son existence tourne à vide.

7 Ces limbes ressembleraient fort aux cercles de l'enfer si l'univers autiste dans lequel le temps et l'espace n'ont ni fin ni finalité, n'était pas, malgré tout, soumis de l'extérieur à l'érosion du temps, et à la pression de l'histoire. L'angoisse que suscite chez le personnage le sentiment confus de la menace d'implosion qui pèse sur l'ensemble de la structure, ne fait d'abord qu'accélérer l'errance affolée dans les passages qui sont à la fois un refuge et un piège. Ainsi Miss Hare parcourt-elle les dédales de sa maison vide qui sont à l'image de son propre désarroi :

Very slowly at first she had begun to negotiate the cells and corridors of Xanadu, together with the spiral of her own skull, gathering impetus as the gusts of fear and hatred played upon her out of the remaining shreds of curtains. (RC 420)

Le mouvement pour échapper à la claustrophobie du vide, ne cesse qu'à l'implosion de la structure entière, dont l'artifice est ainsi révélé. Car cette structure architecturale dans laquelle s'inscrivent les passages, n'est en fait que la concrétisation de la tentative d'imposer un ordre à une réalité qui, dès le premier roman de White, est perçue comme chaotique : "Putting up a structure in the face of shapelessness, building, if not in brick or stone, a resistance to annihilation $»^{5}$. 
Or le défaut de construction des grandes structures architecturales qui apparaissent tout au long de l'œuvre, se situe dans l'inadéquation entre la vision qui les a conçues et le contexte australien. Ici le terme "passage" devra être pris dans un sens non plus architectural mais citationnel, l'enfermement étant cette fois le résultat d'une structuration abstraite héritée d'un modèle culturel associé à la figure du père. Ainsi Norbert Hare conçoit-il sa demeure, "Xanadu», comme une sorte de manifeste romantique. Mais cette maison qui est la concrétisation d'une beauté idéale, plaquée sur une réalité que Norbert Hare refuse de prendre en compte, est dès le premier jour un caprice incongru et une ruine en sursis :

[He would stare] out over his own property. Or beyond, it could have been-[...] beyond even the grey, raggedy, native scrub, for his eyes appeared momentarily appeased, and that end might not have been achieved, if anchorage in time and space had forced him to recognize the native cynicism of that same, grey, raggedy scrub. (RC 15)

10 À la fin du roman, l'espace australien et le temps historique reprennent évidemment leurs droits sur un mythe déraciné et Xanadu disparait : « Xanadu had been shaved right down to a bald, red, rudimentary hill » (RC 486).

11 Pourtant la mise en équivalence du mythe et de la réalité est parfois fructueuse et leur superposition enrichissante. C'est le cas dans The Aunt's Story où le nom mythique de Meroë semble correspondre parfaitement aux terres sur lesquelles la famille Goodman vient s'installer :

Someone had called it [Meroë], and no one in the district remembered why. It had been accepted along with the other exotic names [...] that have eaten into the gnarled and aboriginal landscape and become part of it. [...] No one ever debated why their flat daily prose burst into sudden dark verse with Meroë in their mouths. Meroë, they said, in their flat and dusty local accents. Although the word smouldered, they were speaking of something as unequivocal as the hills. Only the hills round Meroë had conspired with the name, to darken, or to split deeper open their black rock, or to frown with a fiercer, Ethiopian intensity. The hills were Meroë, and Meroë was the black volcanic hills. ${ }^{6}$

12 Mais George Goodman, épris de tragédie antique, ne perçoit la correspondance que pour se réfugier dans l'abstraction du mythe éthiopien, et c'est ainsi que la vitalité austère de Meroë se tarit dans les passages de la maison, sans que la jeune Theodora Goodman puisse repousser la fin inévitable :

She walked out through the passages, through the sleep of other people. She was as thin as grey light, as if she had just died. [...] So she went outside where the grey light was as thin as water and Meroë had in fact dissolved. [...]

Meroë was grey water, grey ash. (AS 85)

13 Se libérer de l'enfermement des passages, c'est d'une certaine façon mourir au monde du passé en renonçant à l'héritage d'un décentrement du sens, qu'il soit associé à railleurs du « Home » ou encore au dualisme de l'idéalisme platonicien. Les personnages de White ne viennent au monde du présent authentiquement australien qu'en découvrant un véritable mode de passage entre la conscience et le monde, et réciproquement entre la matière et l'essence.

14 La saisie directe de ces passages est impossible, du fait qu'ils sont pur dynamisme, sans épaisseur spatiale ni temporelle, dans un univers sans cloisonnement. White les suggère donc par le biais de la beauté insaisissable d'objets ambivalents, et plus particulièrement 
par l'évocation de la lumière qui mieux que toute chose unit la particule de matière et l'immatérielle énergie :

The face transcended a vulgarity of superficial, slippery paint, to reveal a correspondence, as will some of the semi-precious stones, of flowers, or phrases of music, or passages of light. ${ }^{7}$

White s'appuie sur ces objets catalyseurs de correspondance pour mettre en évidence ce qui pour lui est le fondement même de la poésie. Non pas une poésie formalisée ou institutionnalisée, mais un mode de "passage » intemporel et immobile qui dans The Eye of the Storm peut être intuitivement perçu même par le notaire compassé de Mrs Hunter qui est pourtant le moins poétique des hommes :

Flesh was translated into light air nothing all. Perhaps this was what others know as " poetry » and which, he would have had to confess, he was unable to recognize on the page. (ES 578)

Presque toujours dans l'œuvre de White, l'écrit est déconsidéré comme mode de passage poétique. Les livres sont rarement des vecteurs d'illumination du fait de la nature essentiellement abstraite du mot. «Words are not what make you see » dit Miss Hare, et c'est en général le peintre que White choisit de décrire en poète visionnaire.

Cependant, tout en dénonçant sans cesse l'absence de texture et de chatoyance des mots, White s'en sert précisément comme des objets dont il fait jouer toutes les facettes à la lumière de l'interprétation du lecteur. La mise-en-jeu de la polysémie du mot prend la forme d'une sorte de "translation» d'un niveau de sens à un autre. En effet, si la translation - au sens de transport ou transfert d'un corps constitué dans l'espace et le temps - est impossible dans l'univers indifférencié des passages inscrits dans les structures fermées, par contre, la translation paradigmatique est fructueuse, et White s'en sert à plusieurs niveaux de son écriture.

Il multiplie ainsi les jeux de mots qui font intervenir les différents niveaux de conscience d'un personnage, ayant parfois recours à une translation-traduction, comme dans ce passage de Riders in the Chariot ${ }^{8}$ où White utilise le discours prétentieusement orné de mots de français mal prononcés (" petty point» et «croaky de poison ») de Mrs Jolley pour évoquer en filigrane sa mesquinerie, et pour suggérer qu'elle a empoisonné son mari. L'aller-retour entre l'anglais et le français, « des fish fingers » aux « croquettes de poisson " aux mots "poison» et "croak» relève du même fonctionnement que la traduction, sur différents niveaux de sens, du mot «stroke» par exemple. Dans The Vivisector, "a stroke» désigne la crise cardiaque qui laisse le peintre à moitié paralysé, mais aussi dans une lettre d'un personnage secondaire au héros du roman, la caresse de la grâce :

Some years past I suffered a mild stroke, and you recently a worse. [...] we was all perhaps stroked by God. [...] I believe the afflicted to be united in the same purpose, and you of course as an artist and the worst afflicted through your art can see farther than us who are mere human diseased. ${ }^{9}$

White reprend ainsi avec une ironie qui n'est cependant pas un démenti l'exergue rimbaldien du roman :

He becomes beyond all others the great Invalid, the great Criminal, the great Accursed One-and the Supreme Knower. For he reaches the unknown. Les «passages » que constituent les jeux sur les mots n'ont donc pas qu'une portée de simple détail. Parfois, ils sont même à l'origine de la structuration de l'ensemble du 
roman, comme dans Riders in the Chariot, dont l'unité dépend du rapport entre la fête juive « Passover » et la Pâque chrétienne.

Dans ce roman, White décrit une société australienne caricaturalement matérialiste qui fonctionne repliée sur elle-même en excluant toute « anomalie », que ce soit la difformité physique et mentale incarnée par Miss Hare, la monstrueuse générosité et l'amour désintéressé de Mrs Godbold, la couleur et la culture d'Alf Dubbo l'aborigène, ou la religion du Juif Himmelfarb. En système fermé, la société de Barrenugli est un enfer, mais les quatre personnages parviennent, en faisant jouer leurs différences, à créer un passage vers l'unité spirituelle. Le point culminant du récit intervient au moment de l'année où coincident Pâques et la fête du Pessach :

Passover and Easter would fall early that year. The heavy days were still being piled up, and no sign of relief for those who were buried inside. Little wonder that the soul hesitated to prepare itself, whether for deliverance from its perennial Egypt, or redemption through the blood of its Saviour, when the body remained immured in its pyramid of days. (RC 373)

Pessach est d'abord la fête du " passage » du Seigneur au-dessus des maisons des enfants d'Israël pour confirmer l'hermétique protection contre le chaos qui va régner à l'extérieur. Mais White insiste davantage sur la symétrie entre la libération du peuple d'Israël, et la rédemption des péchés par le sacrifice du Christ. Il suggère que les deux systèmes religieux qui s'obstinent dans leurs rites séparés tournent à vide. "The papiermâché symbols of Pessach » sont aussi insignifiants que l'amabilité de circonstance des " plastic ladies » chrétiennes (382). Même Himmelfarb désespère de célébrer Seder, la fête de libération :

He had to face the disaster of his Seder table. Still untouched, the past few hours seemed to have made a sculpture of it, not of rejoicing, but of lament. Here rather, was the tomb of all those, including himself, who had not survived the return journey. (RC 395)

Mais l'espoir renaît lorsque Himmelfarb s'aperçoit que le morceau d'agneau de la Pâque chrétienne que lui a donné Mrs Godbold est presque identique à celui qu'il a sur sa table :

Then the Jew saw that he was still carrying Mrs Godbold's dish, and that the wretched shankbone which his neighbour had brought as an offering was almost the twin of the one he had laid that afternoon on his own Seder table. (RC 395)

La correspondance entre la foi chrétienne et la foi juive est confirmée plus tard lorsque le Juif est crucifié par des Chrétiens. L'inversion de l'Écriture Sainte revitalise le mythe et l'universalise par-delà les différences d'appartenance religieuse.

Le fait que les correspondances fonctionnent également aux différents niveaux de l'œuvre correspond bien à la volonté de White d'établir une tension illuminante entre ce qu'il considère dans tous les cas être les pôles complémentaires d'une même vérité, ellemême solidaire avec le "Tout». Les correspondances unifiantes ainsi établies rendent bien sûr caduque la notion d'enfermement, du fait que les oppositions du plein et du vide, de l'intérieur et de l'extérieur ne tiennent plus. Ceci ne contredit pas les citations de Paul Éluard et de Maitre Eckhart en exergue du roman The Solid Mandala dans lequel White a le plus théorisé sa perception du monde :

There is another world, but it is in this one.

It is not outside, it is inside: wholly within.

Il est en effet difficile d'exprimer l'unité dans la différence et il serait réducteur de prendre ces citations à sens unique. Il ne s'agit pas en effet de nier la transcendance au profit d'une conception immanente du monde, mais bien de suggérer une immanence 
transcendantale. Le Christ est la figure par laquelle White met le plus souvent en évidence cette dynamique unifiante entre la transcendance et l'immanence :

All remembered the face of Christ that they had seen at some point in their lives, either in churches or in visions, before retreating from what they had not understood, the paradox of man in Christ, and Christ in man. (Voss 342)

Le paradoxe est traduit poétiquement par Dubbo, le peintre aborigène qui, en assistant à la scène parodique de la crucifixion de Himmelfarb, "comprend" enfin le sacrifice christique en une image que White a progressivement élaborée tout au long du roman :

Instinct and the white man's teaching no longer trampled on each other. As he watched, the colour flowed through the veins of the cold, childhood Christ, at last the nails entered wherever it was acknowledged they should. (RC 412)

À l'intérieur du roman, Dubbo est l'artiste qui perçoit et transcrit la correspondance entre le grotesque horrible de la scène réelle et la souffrance rédemptrice de la scène biblique. Et son activité est à l'image du travail de White qui se sent investi de la mission d'établir des passages entre un système social ou une situation individuelle et une structure mythique, le mouvement dialectique de l'un à l'autre constituant la finalité même de son art, qui est une garantie contre l'enfermement dans un système bloqué.

\section{NOTES}

1. «There is a stubborn, bitter ring if you kick at a piece of black rock. And how would serene, Christian, German, eighteenth century Johann Sebastian have dealt with a lump of antipodal rock? Serenity perhaps was the effect of environment, not so much the result of spiritual conflict. At least you would like to think that. It would make things easier. You could give up the ghost at once. », Patrick White, Happy Valley, London, Harrap, 1939, 20.

2. Riders in the Chariot, Harmondsworth, Penguin, 1975, 294.

3. The Tree of Man, Penguin, 1970, 177.

4. «The moment we are born, we start to degenerate. Only the unborn soul is whole, pure. [...] Tell me, Mary, do you consider yourself one of the unborn? », RC 36 .

5. The Living and the Dead, Penguin, 1970, 17.

6. The Aunt's Story, Penguin, 1975, 20.

7. The Eye of the Storm, 1975, 19.

8. Riders in the Chariot, 224. L'image de la mère patrie qui est une figure topique de l'imaginaire whitien, est explicitée dans des discours comme «Patriotism » (1984), ou "State of the Colony " (1981) : « What I deplore about this country is that those who are running it are not in step with modern times. They would like us to remain the Grazier's reactionary colonial sheep run, they yearn to creep back inside Big Mummy's cosy womb and lie blissfully oblivious of the demands of life, the advance of history. » ("State of the Colony », in Patrick White Speaks, 92.)

9. The Vivisector, Penguin, 1988, 613. Des jeux de mots de ce genre peuvent sembler de mauvais goût et artificiels comme le suggère John Colmer, lorsqu'il écrit à ce propos : « It is surely only a trivial mind that can find deep meaning in the two senses of "stroke" in this context. [...] The pretentious artifice calls attention to the means, to the strenuous effort of the fancy and the will. ». John Colmer, "Duality in Patrick White", in Patrick White. A Critical Symposium, ed. Ron Sheperd and Kirpal Singh, Adelaide, Centre for Research in the New Literature in English, 1978: 
71-72. C'est sans doute en manière de réponse (plus ou mois ironique) à des critiques de ce genre que White se lamentait de n'être qu'un peintre raté.

INDEX

oeuvrecitee Riders in the Chariot, Tree of Man (The), Aunt's Story (The), Happy Valley, Voss 